\title{
The effect of military social responsibility perception on soldier's organizational citizenship behavior (OCB)
}

\author{
Cheonseok Park $^{*} \cdot$ Jeman Jeon ${ }^{* *}$
}

This research aims to study the social role of the military, which is expected to gain importance when the security environment of the Korean Peninsula changes in the future. Expanding the research on corporate social responsibility (CSR), this study redefines the concept of military social responsibility (MSR) and identifies the impact of MSR perception on soldiers' organizational citizenship behavior (OCB). This study aims to examine the effects of MSR on OCB and the mediating effect of reputation. Thus, the survey was conducted by visiting two army troops in the metropolitan area and three army troops in the Gangwon-do area. As a result, MSR perception by military service members had a significant positive (+) effect on OCB. In addition, reputation showed a significant partial mediating effect. Further, for individual MSRs, legal and ethical MSR and philanthropic MSR had a significant positive $(+)$ effect on OCB, and reputation was fully mediated

(a) (1) This work is licensed under a Creative Commons Attribution 4.0 International License.

* (First Author) Korea Army Academy at Yeongcheon, Department of Public Administration, Instructor, parkchunseok@naver.com ** (Corresponding Author) The ROTC at the University of Seoul, Disciplinary Officer, wjswpaks@naver.com 
in that process. Finally, based on the results, the implications of the study and future research directions were discussed.

Keywords : military social responsibility, reputation, organizational citizenship behavior, social identity theory, mediate effect 


\section{I. 서론}

‘군의 사회적 책임' 주제를 선정한 배경은 다음과 같다. 첫째, 현재 다양한 분야에서 활발하게 연 구되고 있는 '기업의 사회적 책임'을 확장해 그 대상을 군으로 넓혀 '군의 사회적 책임'에 대한 개념 을 정립하고자 한다. 기업의 사회적 책임은 1950 년대부터 학문적으로 논의가 시작된 이래, 그 정의 와 범위, 중요성 측면에서 다양하게 논의되었으며, 현재는 다양한 학문에서 활발하게 연구가 진행 되고 있다. 반면, 군의 사회적 책임은 그 용어조차 생소하다. 그러나 Carroll(1991)이 주장한 4가지 기업의 사회적 책임의 주체를 기업에서 군으로 바꿔본다면, 군은 이미 생각보다 다양하고 많은 법 적, 윤리적, 자선적 책임활동을 전 국민을 대상으로 실시하고 있다. 그 예로 2019년 강원도 산불, 2020년 코로나 19 등 국가적 재난 상황 발생 시 국방부의 대민지원 활동을 들 수 있다. 또한, 재난 상황과는 별개로 평소 장병이 실시하는 지역사회 자원봉사활동 등이 있다. 본 연구는 군에서 실시 하는 다양한 사회적 책임 활동을 기업의 사회적 책임 연구틀(frame)를 활용하여 해당 개념을 정립 하고자 하였다.

둘째, 미래 한반도 안보환경 변화에 따라 군에게 새롭게 혹은 더 막중하게 부과될 군의 사회적 임무(역할)가 군 장병에 미치는 영향에 관해 알아보고자 한다. 과학기술이 지속적으로 변화 및 발 달함과 동시에 미래 전쟁의 양상과 위협의 형태, 크기 또한 다양해졌다. 안보전문가들은 변화될 안 보환경의 특징으로 사이버, 테러, 재해, 재난 등 초국가적이고 비군사적인 위협이 높아질 것으로 예 측한다. 이러한 테러, 재해, 재난 등 초국가적이고 비군사적 위협에 대한 대응은 곧 군의 필수적이 고 핵심적인 임무로 자리 잡을 것으로 판단된다. 이러한 점에서 군의 사회적 책임 연구 및 그러한 군의 사회적 책임 활동이 군 장병의 행동에 미치는 영향에 관한 연구의 필요성이 제기된다.

이에 본 연구는 (1) CSR 연구틀을 확장해 군의 사회적 책임에 대한 개념을 정립하고, (2) 군의 사회적 책임 활동이 조직 구성원의 이타적 행동에 미치는 영향을 확인하는데 그 목적이 있다. 세부 적으로 군 장병이 인식하는 군의 사회적 책임 활동 중 어떠한 하위 요소가 어떤 메커니즘을 통해 이타적 행동에 영향을 주는지 확인하고, 평판(reputation)의 매개효과를 검증한다.

\section{ㅍ. 이론적 배경}

\section{1 기업의 사회적 책임과 군의 사회적 책임}

먼저, 기업의 사회적 책임(Corporate Social Responsibility, CSR)의 경우, CSR에 관한 이론과 연 구가 본격적으로 체계화되고 학술적으로나 실무적으로 이론화되기 시작한 것은 1960년대 후반부 터 1970년대이다. Frederick(1960)은 기업가의 사회적 책임을 사람들의 기대를 충족시키는 경제적 
시스템을 운영하고 감독하는 것’이라고 정의했으며, Davis \& Blomstrom(1966)은 '기업가의 의사결 정과 행동이 사회 시스템에 미치는 영향력을 고려하는 것'이라고 사회적 책임을 정의하였다. 최근 $\mathrm{CSR}$ 에 대한 공통적인 의견은 $\mathrm{CSR}$ 이 기업의 이미지 제고를 위한 단순 자선 활동 수준을 넘어서, 기업이 사회적 목표와 경제적 목표를 동시에 달성하는 지속가능경영을 위한 새로운 패러다임이라 는 것이다(Porter \& Kramer, 2006).

시대적 상황, 다양한 관점별로 $\mathrm{CSR}$ 에 대한 정의, 구분, 책임 범위 등에 대해 학자들 간의 의견이 차이를 보이지만, 가장 많이 받아들여지는 CSR 개념은 Carroll(1991)의 개념이다. 캐롤은 CSR을 '기업의 사회적 책임은 사회가 조직(기업)에 대해 가지는 경제적, 법적, 윤리적, 자선적 기대를 달성 하는 것'이라고 정의하며, CSR 영역을 경제적 책임, 법적 책임, 윤리적 책임, 그리고 자선적 책임이 라는 4가지로 세부 분류하였다. 캐롤의 4 가지 책임은 경제적 책임부터 자선적 책임까지 뒤로 갈수 록 높은 수준의 책임의 형태를 의미하기 때문에 이를 피라미드 형태로 제시하였다. Carroll(1991)에 따르면, 가장 기본적인 수준의 $\mathrm{CSR}$ 인 경제적 책임은 기업이 생산 활동이 기본 단위로서 사회에서 필요한 제품 혹은 서비스를 생산하여 판매하고 이윤을 창출할 책임을 의미한다. 법적 책임은 기업 이 사회구성원 모두가 약속한 법적 체계 내에서 경제적 활동을 해야 하는 것을 의미하며 윤리적 책임은 법적 강제성은 없으나 기업이 사회의 일원으로서 수행하도록 기대되는 활동을 의미한다. 자 선적 책임은 기업의 자발적인 판단이나 선택이 개입하는 부분으로, 기업이나 경영자가 자발적으로 경영활동과 직접 관련이 없는 사회적 활동을 수행하는 것을 의미한다. 예를 들어, 사회적 기부, 사 회복지시설 운용 등이 있다.

1970 년대 이후 많은 CSR 학자들은 CSR의 효과성 또는 CSR과 기업의 성과 사이에 인과관계를 증명하기 위해 다양한 연구를 활발히 진행하였다. 초기에 진행되었던 대부분 연구들은 CSR과 기 업의 '재무 성과' 간의 긍정적 관계를 증명하는데 초점이 맞춰졌다(Chang \& Ahn, 2012). 그러나 이 후 다수의 리뷰 연구들은 $\mathrm{CSR}$ 과 재무적 성과 간에 관계가 대부분 긍정적이지만 일관된 정 $(+)$ 의 관계를 보이지는 않는다는 결론을 내렸고(Kim \& Lee, 2013; Roman, Hayibor, \& Agle, 1999), 이를 보완하기 위해 CSR 학자들은 '다양한 개인들이 CSR을 어떻게 인식하는가'와 같은 미시적 관점 연 구의 필요성을 제안하였다(Aguinis \& Glavas, 2012). 조직의 경영자와 이해관계자들은 해당 기업 에서 실제로 이루어지는 CSR 활동 또는 CSR 관련 투자에 대해 다르게 인지할 수 있다(Glavas \& Godwin, 2012). 또한, 똑같은 CSR 활동을 인지하더라도 개인 성향이나 가치관에 따라 다르게 반응 할 수 있기 때문이다(De Roeck \& Maon, 2018; Gond, et al., 2017). 이러한 점에서 이해관계자의 $\mathrm{CSR}$ 인지 측면을 고려한 개인수준에서 CSR 연구가 이루어질 필요가 있다. 최근 선행연구는 개인 수준에서 조직구성원의 CSR 인식과 반응을 연구하고 있다(Brammer, et al., 2007; Gond, et al., 2017; Peterson, 2004).

반면, 군의 사회적 책임(Military Social responsibility, 이하 MSR)에 대한 선행연구는 1건으로 $\mathrm{Pyo}(2013)$ 는 MSR 개념을 국군의 사명이라는 군의 본질적인 책임으로부터 식별하여 '군이 국민의 
행복을 위해 사회적 가치를 창출할 수 있는 방향으로 의사결정과 행동을 해야 하는 책임'으로 정의 하고 7가지 책임(당위적, 윤리적, 법적 등)으로 구분하였다. 이 밖에 군의 사회적 책임이라는 개념 을 언급한 선행연구는 전무하다. 그러나 MSR 중 실제적인 군의 대표적인 사회적 책임 활동이라 할 수 있는 ‘병사들의 봉사활동' 또는 ‘군의 재난관리’를 주제로 다룬 선행연구들은 일부 존재한다. Hwang(2012)은 병사들의 자원봉사활동과 군 복무 스트레스, 군 생활 적응 간의 관계를 밝혔으며, Yoo(2016)은 포괄적 안보 측면에서 재난 발생시 군의 역할 증대 방안을 제시하였다. 선행연구들을 종합해보면, 대부분 MSR 활동 중 자선적 활동에 포함될 수 있는 군의 대민지원과 관계된 선행연 구로 국한되어 있으며, 이는 앞에서 언급한 Carroll(1991)의 CSR 관점으로 보면 다소 좁은 범위의 연구라 할 수 있다.

$\mathrm{MSR}$ 에 대한 연구를 위해서는 그 개념과 구성요소 정립이 매우 중요하다. 기존에 선행되었던 $\mathrm{Pyo}(2013)$ 의 MSR 개념 및 7가지 하위요소는 군인의 본질적 - 실천적 책임을 '헌법과 법률'로부터 도출하여 개념화하였다는 점에서 $\mathrm{MSR}$ 의 실체와 가장 가깝다고 볼 수 있다. 그러나 MSR를 하나의 측정 가능한 변수로서 개념화 및 조작화하기 위해 기존에 체계적으로 검증된 CSR의 연구틀을 활 용하였다. 따라서 본 연구에서는 MSR의 정의를 Aguinis \& Glavas(2012)의 CSR 정의로부터 도출 하여 '군을 둘러싼 이해관계자의 기대사항을 반영하여 전투력, 사회, 환경 측면의 성과를 높이는 조 직의 활동 및 정책이라고 정의하였으며, 구성요소는 Carroll(1991)의 CSR 하위차원과 Porter \& Kramer(2006)의 전략적 요소를 바탕으로 MSR의 하위차원을 정의하였다.

그리고 본 연구는 최근 $\operatorname{CSR}$ 연구의 흐름에 따라, 조직구성원들의 CSR 인식과 관련된 개인수준 CSR 연구를 군 맥락에 적용하였으며, 두 가지 이유에서 병사들의 CSR 인식과 관련된 개인수준의 연구가 군 맥락에서 중요하다고 판단하였다. 첫째, 2019년 8월 14일 발표된 국방부 '2020 2024 국 방중기계획'에 따르면 군대는 2019년 말 기준 상비병력 57만 9,000명 중 66\%인 38만 1,000명이 병 사, $34 \%$ 인 19 만 8,000 명이 간부(장교, 부사관) 신분으로, 군 조직구성원 중 의무복무 중인 병사의 비율이 약 $2 / 3$ 로 상당수를 차지하고 있다. 또한, 실제 군의 사회적 책임 활동(재해 - 재난 복구지원, 지역 자원봉사 활동 등)에 주로 참여하는 주체가 병사로 군 간부보다 병사가 인지하는 군의 사회적 책임 활동이 중요하다고 볼 수 있다. 둘째, 군 조직의 구성원인 병사들은 의무복무 기간 18 개월 동 안 군인 신분으로 군에 헌신하지만 이후 의무복무 기간이 충족되면 대부분 전역을 함과 동시에 다 시 민간인 신분으로 군의 보호를 받고, 때로는 군을 평가하는 국민의 한 사람이 된다. 즉, 기업으로 비유하자면, 잠시 종업원이자 평생의 고객인 셈이다. 따라서 복합 이해관계자(조직구성원이면서 고 객) 성격을 떤 병사가 군의 사회적 책임을 어떻게 인식하고 그러한 인식이 그들의 행동에 미치는 영향을 파악할 필요가 있다. 


\section{2 조직시민행동}

조직시민행동은 '공식적인 보상시스템에 의해서 명백히 인식되지 않지만, 조직의 효과적인 기능 을 촉진하는 개인의 자유 재량적 행동'으로 이타주의(Altruism), 양심(Conscientiousness), 스포츠 맨십(Sportsmanship), 예의(Courtesy), 시민행동(Civic Virtue)의 5가지 차원으로 분류된다(Organ, 1988). 이타주의란 휴가 중인 동료를 돕거나 새로 전입을 와 과업 해결에 어려움을 겪는 다른 조직 구성원을 돕는 모든 행동을 의미하며, 수혜대상이 구체적인 대상이 있다는 점에서 양심과 구별된 다. 양심이란 업무시작 전에 출근하거나 근무시간에 개인적인 용무를 보지 않는 등 조직 내에서 지 켜야 할 규칙을 엄수하고 본인의 정해진 역할을 제대로 수행하는 것을 의미한다. 스포츠맨십이란 조직 내에서 겪는 사소한 문제나 고충에 대해 불평보단 조직 전체를 위해 인내하는 행동을 의미한 다. 예의란, 업무와 관련하여 다른 사람과 발생할 수 있는 문제를 사전에 방지하고자 하는 배려 행 동을 의미하며, 시민 행동이란 조직 내의 회의나 회식 등 활동에 적극적으로 참석하거나 조직의 다 양한 정책이나 활동에 관심을 갖는 것을 의미한다. 조직시민행동의 선행연구는 주로 선행변수의 탐 색에 초점을 두어 연구가 진행되었으며, 조직시민행동에 영향을 주는 대표적인 선행 요인으로 직무 만족, 조직몰입, 조직공정성, 리더십, 과업특성과 개인특성 등이 있다(Kim, 2000). 본 연구에서는 조 직시민행동을 Organ(1988)의 개념 중 어려움을 겪는 다른 사람을 돕는 '이타주의'에 초점을 맞춰서 연구를 진행하였다.

군이라는 조직의 특수성을 고려했을 때, 조직시민행동 변수는 중요하다. 전혀 경험해보지 못한 환경에서, 전혀 모르는 사람들과 일정 부분 개인의 자유를 통제받으며 실시하는 군 복무는 의무복 무를 해야만 하는 군 장병에게 있어서 모든 면에서 어렵다. 또한, 군 지휘부도 서로 다른 욕구를 가진 다양한 개인들을 군 복무 간 개인의 목표보다 조직의 목표를 위해 복무토록 지휘해야 하고 단결시켜야 한다. 특히, 군 조직 및 조직구성원의 특수성을 고려할 때, 군 장병들의 적응, 화합, 단 결에 긍정적인 영향을 미칠 수 있는 변수로 공식적인 보상과 관계없이 다른 조직 구성원을 돕는 이타적 행동 변수인 조직시민행동의 역할이 중요하다고 볼 수 있다.

\section{3 평판}

Fombrun, et al.(2000)은 평판을 '가치 있는 결과를 여러 이해관계자에게 제공할 수 있는 회사의 능력을 나타내는 회사의 과거 행동과 결과의 종합적인 표현(collective representation) 또는 그 능 력에 대한 종합적인 평가’라고 정의했다. 평판의 구성요소는, ‘무엇이 평판을 결정짓는가?'와 관련 된 문제이며, 이는 평판을 측정하는 방법론과 관련이 깊다. Lewis(2001)는 평판의 구성요인으로 제 품이나 서비스의 질, 기업의 경영철학, 사회적 책임, 근무환경 등을 꼽았으며, Rayner(2004)는 경영 성과, 장기적인 투자가치, 커뮤니케이션, 법규 준수 등을 주장했다. Fombrun, et al.(2000)은 포츈지 
The effect of military social responsibility perception on soldier's... / Cheonseok Park • Jeman Jeon 139

를 포함하여 8 개의 기존 평판 조사 도구들을 종합적으로 분석하여 총 20개의 항목을 추려낸 뒤, 이 를 다시 여러 단계를 거쳐 총 6차원의 요인(감성적 소구, 제품과 서비스, 비전과 리더십, 작업환경, 사회적 책임, 재무적 성과)으로 분석했다. '감성적 소구'란 그 기업에 대한 호감, 존경, 신뢰 등에 대 한 측정이며, ‘제품과 서비스'는 품질 혹은 서비스에 대한 우수성을 측정, ‘비전과 리더십'은 기업 혹은 기업경영자가 가진 미래에 대한 비전에 대한 물음, '작업환경'은 좋은 업무환경에 대한 물음이 다. '사회적 책임'은 기업이 훌륭한 사회의 일원으로 행동하는지 여부에 대한 측정, '재무적 성과' 기업이 이윤을 충분히 내는지, 재무적으로 건전한지에 대한 측정이다. 이러한 선행연구들을 종합적 으로 살펴본 결과, 군에 대한 평판을 Fombrun, et al.(2000)의 구성요소로 선정한다.

\section{4 사회정체성 이론}

사회정체성 이론(Social Identity Theory)에 따르면, 사람들은 직종, 종교, 출신 지역 등 다양한 사회적 범주로 자신과 다른 사람들을 분류하는 경향이 있다(Ashforth \& Mael, 1989). 이러한 사회 적 범주화는 개인이 스스로 자신이 속한 사회적 환경(특성)으로 자신을 정의하도록 한다. 즉, 개인 이 가진 자아개념(self-concept)을 자신이 속한 사회적 범주로부터 도출된 모든 이미지 혹은 특징 등으로 자신의 사회적 정체성(social identity)을 형성한다는 것이다. 이러한 과정에서 개인은 특정 사회 혹은 집단과 일체감을 느끼거나 소속감을 느끼게 되는데 이러한 현상을 사회적 동일시라고 한다(Katz \& Kahn, 1978; Turner, 1984). 이러한 사회적 동일시 과정에서 개인들은 집단의 특성을 자신의 것으로 인식하거나 집단의 운명을 공유하면서 개인의 정체성(혹은 자아개념)을 변화시키게 된다(Mael \& Ashforth, 1992).

\section{III. 연구 모형 및 가설설정}

\section{1 군의 사회적 책임(번들)의 효과 : 연구 1}

\subsection{1 군의 사회적 책임과 평판}

Fombrun, et al.(2000)에 따르면, 기업은 지역사회를 위한 사회적 책임 활동을 통해 호의적인 기 업 평판을 구축할 수 있다. 기업의 CSR 활동이 사회적 요구에 대한 반응성(responsiveness)으로서 이해관계자들의 기업에 대한 건설적인 기여를 장려하는 데 도움이 된다면, 그러한 CSR 활동은 경 영자는 물론 다른 이해관계자(주주, 직원, 소비자, 지역사회 등) 모두의 기대를 충족시키기 때문에 회사의 평판을 높일 것이다(Donaldson \& Preston, 1995). Brammer \& Pavelin(2006)은 기업의 CSR 활동이 기업 평판에 미치는 영향을 실증적으로 확인했다. Minor \& Morgan(2011)은 다양한 
사례를 통해 CSR 활동이 위기관리 전략 측면에서 중요한 역할을 하며, 이는 평판 보험(insurance) 으로서 기능한다고 주장했다. 미시적 관점에서 수행된 CSR 선행연구로 조직구성원이 지각하는 CSR과 조직 평판 간의 유의한 정(+)의 관계를 밝힌 Cho et al. (2014)의 연구가 있다. 사회정체성 이론에 따르면, 개인의 자아개념은 그들이 근무하는 조직 혹은 속한 사회집단 멤버십에 영향을 받 으며(Ashforth \& Mael, 1989), 개인은 긍정적인 사회정체성을 추구하고자 한다(Tajfel \& Turner, 1985). 또한, 조직의 윤리, 가치 및 사회적 활동에 대한 직원의 인식이 해당 조직에 대한 매력에 영 향을 미칠 수 있는 바(Greening \& Turban, 2000), 군에서 실시하는 군의 사회적 책임 활동에 대한 인식은 군 장병의 긍정적인 사회정체성과 군에 대한 매력에 영향을 미칠 수 있을 것이다.

본 연구는 '평판'을 현재 복무 중인 군 장병이 자신의 부대를 직접 평가한 내부 이해관계자의 평 판으로 가정하였다. 그래서 외부의 이해관계자가 아닌 내부의 이해관계자가 측정하여 그 측정결과 에 대한 객관성 문제를 제기될 수 있다. 그러나 본 연구의 연구대상은 현재 의무 군 복무 중인 현역 장병이다. 의무복무 중인 군 장병은 현재는 내부 이해관계자지만, 불과 몇 개월 전에는 군의 외부 이해관계자인 국민(민간인) 중 한 사람이었으며, 18 개월 혹은 더 짧은 시간 이내에 다시 민간인 신 분으로 돌아가는 특수한 이해관계자 신분이다. 이러한 연구대상의 특수한 신분을 고려할 때, 본디 평판이 지닌 개념은 '경험에 근거한 일정 기간 동안 구축되어 조직의 자질에 대한 가치 판단(Chun, 2005)'으로 볼 수 있으며, 현재 의무복무 중인 군 장병이 평가하는 군의 평판은 오히려 더 정확한 군에 대한 평판이 될 수 있다. 상기한 이론적 관계를 토대로 다음과 같은 가설을 설정하였다.

가설 1: 군의 사회적 책임은 평판과 정(+)의 관계가 있을 것이다.

\subsection{2 평판과 조직시민행동}

최근 연구에 따르면 조직구성원은 조직 내에서 그들의 행동이 가치 있는 행동이라고 느낄 경우, 또는 그들이 속한 조직이 선한 행동을 하는 조직이라고 인지할 경우, 그들은 동료나 관리자를 더 도울 가능성이 높다(Rego, Ribeiro, \& Cunha, 2010). 또한, 본인이 속한 조직이 사회적 책임과 관련 된 평판이 높다고 인지할 경우 조직원들은 해당 기업의 긍정적인 대변인으로 행동할 가능성이 높 으며(Morhart, et al., 2009), 조직시민행동을 행할 가능성이 높다(Fu, et al., 2014).

관련 선행 연구로 Mehtap \& Kokalan(2013)는 4개 TV 기업과 4개 은행을 대상으로 실시한 비교 연구를 통해 기업 평판이 임직원들의 조직시민행동에 긍정적인 영향을 미침을 증명했다. 비슷한 선 행연구로 Akturan와 Şevik(2016)의 연구 또한 기업평판이 OCB에 미치는 영향에 대해 실증 분석하 였다. Fu, et al.(2014)는 조직구성원이 인지한 평판이 조직몰입을 매개로 조직시민행동에 긍정적으 로 영향을 미친다는 것을 증명했다. 이때, 직원이 인지한 평판을 '사회적 책임 관련 평판(Social responsibility reputation)과 '임직원 대우 평판(Employee Treatment reputation)'으로 구분하였는 데, 연구결과 두 가지 평판 중 사회적 책임 관련 평판만 조직시민행동에 유의하게 영향을 미쳤다. 
The effect of military social responsibility perception on soldier's... / Cheonseok Park • Jeman Jeon 141

이와 같은 선행연구들은 사회정체성 이론으로 설명할 수 있는데, 사회정체성 이론에 따르면 개인의 자아개념은 조직의 특성에 의해 영향을 받는다. 그러한 측면에서 평판이 높은 조직에서 근무한다는 것은 개인들의 자아 개념을 긍정적으로 강화할 수 있기 때문에(Maignan \& Ferrell, 2001), 우호적 인 평판을 가진 조직에서 근무하는 조직구성원은 자랑스러움을 느끼고 그 결과 그들의 태도는 존 경받는 조직과 연계하여 긍정적으로 영향을 받을 수 있다(Peterson, 2004). 따라서 다음과 같은 가 설을 설정하였다.

가설 2: 평판은 조직시민행동과 정 $(+)$ 의 관계가 있을 것이다.

\subsection{3 군의 사회적 책임과 조직시민행동}

사회정체성 이론에 따르면, 사회적으로 바람직한 기업에 속해 있다고 인지한 조직구성원은 자아 존중감이 형성되고, 이는 조직에 대한 애착과 동일시를 통해 조직구성원의 조직에 대한 긍정적인 직무태도를 연계될 수 있다(Brammer, et al., 2007). 따라서 기업의 CSR 활동은 조직구성원으로 하 여금 바람직한 조직에 속해 있다는 긍정적 소속감과 자아존중감을 불러일으켜 조직시민행동에 긍 정적인 영향을 미칠 수 있다.

다양한 선행연구들은 조직구성원이 인식한 $\mathrm{CSR}$ 활동이 그들의 $\mathrm{OCB}$ 에 긍정적인 영향을 미친다 는 것을 실증적으로 증명하였다. Kwon \& Kang(2012)은 조직구성원이 인식한 윤리적CSR이 OCB 에 긍정적으로 영향을, $\mathrm{Cha}(2013)$ 은 조직구성원이 인식한 법적/윤리적CSR이 OCB에 긍정적인 영 향을 미친다는 것을 보고하였다. Park \& Hahn(2011)도 비슷한 연구결과를 보였는데 조직구성원이 인식한 $\mathrm{CSR}$ 은 그들의 $\mathrm{OCB}$ 에 긍정적인 영향을 주었으며, 이때 기업의 능력을 더 많이 인식할 때 또는 CSR 프로그램에 직접 참여할 때 그 관계가 더 강해지는 것을 실증적으로 확인하였다. Lin, et al.(2010) 실증연구에 따르면, 구성원들의 OCB가 조직구성원들에 의해 지각된 기업의 법적 - 윤 리적 시민행동(Corporate Citizenship)에 의해 긍정적으로 영향을 받았다. 그러나 해당 연구에서 $\mathrm{OCB}$ 는 조직구성원들이 인식한 재량적(discretionary) 시민행동에 의해 부정적으로 영향을 받았는 데, 이는 기업의 한정된 자원(resources)이 기부나 파트너십 스폰서 형태로 외부 유출되는 것에 대 한 조직구성원들의 부정적 인식이 작용했기 때문이다.

본 연구의 연구대상은 이윤 극대화의 목적을 지닌 기업이 아닌 국가 기관으로서 군대이며, 군 복 무 중인 군 장병은 군에서 발생되는 자원과 배분에 대해 이해관계가 없기 때문에, 군에 복무 중인 군 장병의 $\mathrm{OCB}$ 는 군에서 시행되는 모든 종류의 군의 사회적 책임 활동에 긍정적으로 영향을 받을 것이라 예측된다. 따라서 다음과 같은 가설을 설정하였다.

가설 3: 군의 사회적 책임은 조직시민행동과 정 $(+)$ 의 관계가 있을 것이다. 
$\mathrm{CSR}$ 활동이 기업의 평판을 향상시킨다는 선행연구들은 다수 존재하지만, 대부분 조직수준 이상 에서 패널 데이터를 활용한 거시적 관점의 연구였으며, 미시적 수준에서 수행된 CSR 연구 중에서 도 중간 메커니즘에 관한 연구는 드물었다. 이에, 본 연구는 중간 메커니즘으로 평판을 제시한다. 기업의 사회문제 참여는 일반적으로 조직의 평판을 높이기 때문에 기업의 자선활동이나 기부활동 등 사회적 책임활동은 구성원들의 태도와 행위에 긍정적인 영향을 미칠 수 있다(Kwon \& Kang, 2012). Jung \& Shin(2016)는 기업의 윤리적 혹은 자선적 CSR 활동이 기업의 평판 향상이나 지속적 인 성장에 기회를 제공하기에, 그러한 기업의 CSR 활동에 정당성을 지각한 직원들은 정서적으로 조직과 동일시되어 $\mathrm{OCB}$ 를 적극적으로 실천할 수 있다고 주장하였다. 이와 마찬가지로, 사회에 기 여하는 MSR 활동에 정당성을 지각한 군 장병들은 군과 정서적으로 동일시되어 OCB가 발현될 수 있다. 이 과정에서 군 장병들의 군에 대한 긍정적인 평판이 형성되어 MSR 활동와 $\mathrm{OCB}$ 의 관계를 매개할 것이라 예상하였다. 따라서 다음과 같이 가설을 설정하였다.

가설 4: 평판은 군의 사회적 책임과 조직시민행동의 관계를 매개할 것이다.

본 연구 1 의 가설을 토대로 구성한 연구모형은 다음과 같다(그림 1 ).

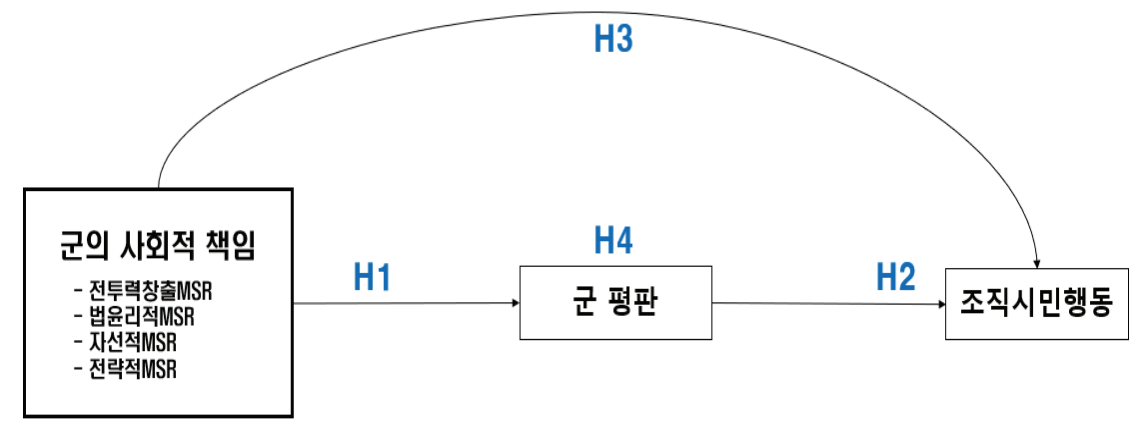

<그림 1> 연구 1에 관한 연구모형

\section{2 군의 사회적 책임 하위요소의 개별 효과 : 연구 2}

연구 2는 군의 사회적 책임 하위요소 4가지(전투력창출MSR, 법윤리적MSR, 자선적MSR, 전략 적MSR)가 각각 조직시민행동에 미치는 개별효과와 해당 관계에서 평판의 매개효과를 검증하기 위해 실시하였다. 연구가설은 표 1 과 같다. 
<표 1> 연구 2 가설 설정

\begin{tabular}{|c|c|}
\hline 가설1 & 군의 사회적 책임은 군 평판과 정(+)의 관계가 있을 것이다. \\
\hline H1a & 전투력창출 $\mathrm{MSR}$ 은 군 평판과 정(+)의 관계가 있을 것이다. \\
\hline $\mathrm{H} 1 \mathrm{~b}$ & 법윤리적 MSR은 군 평판과 정 $(+)$ 의 관계가 있을 것이다. \\
\hline H1c & 자선적 MSR은 군 평판과 정 $(+)$ 의 관계가 있을 것이다. \\
\hline H1d & 전략적 $\mathrm{MSR}$ 은 군 평판과 정 $(+)$ 의 관계가 있을 것이다. \\
\hline 가설2 & 평판과 조직시민행동은 정(+)의 관계가 있을 것이다. \\
\hline 가설3 & 군의 사회적 책임은 조직시민행동과 정(+)의 관계가 있을 것이다. \\
\hline 가설4 & 군 평판은 군의 사회적 책임 활동과 조직시민행동 간의 관계를 매개할 것이다. \\
\hline H4a & 군 평판은 전투력창출 $\mathrm{MSR}$ 과 조직시민행동 간의 관계를 매개할 것이다. \\
\hline $\mathrm{H} 4 \mathrm{~b}$ & 군 평판은 법윤리적 $\mathrm{MSR}$ 과 조직시민행동 간의 관계를 매개할 것이다. \\
\hline $\mathrm{H} 4 \mathrm{c}$ & 군 평판은 자선적 $\mathrm{MSR}$ 과 조직시민행동 간의 관계를 매개할 것이다. \\
\hline H4d & 군 평판은 전략적 $\mathrm{MSR}$ 과 조직시민행동 간의 관계를 매개할 것이다. \\
\hline
\end{tabular}

\section{IV. 연구 방법}

\section{1 연구대상 및 절차}

연구를 위한 표본으로 강원도 지역 육군 3 개 부대, 수도권 지역 육군 2 개 부대 총 5 개부대의 군 장병 332명을 대상으로 2019. 9.2.(월) 9.27.(금), 약 4주간 설문을 진행하였다. 설문 이전에 현역 장 병들을 대상으로 예비조사를 통해 설문 소요 시간 파악, 내용 전달에 어려움을 주는 용어 및 불필 요 문항 등을 식별하여 설문지를 수정 보완하였다. 또한, 군 자체적으로 군내 장병 대상으로 실시하 는 설문에 필요한 보안성 검토 절차를 2019. 8. 28.(수)부로 완료하였다.

설문지 구성은 총 43 문항으로 군의 사회적 책임 24 문항, 조직시민행동 4 문항, 평판 6 문항, 인구통 계학적 조사 9문항을 구성하였고, 리커트 5점 척도(Likert scale)를 활용해 육군 현역 군 장병의 인 식을 측정하였다(1점 '전혀 그렇지 않다' -3점 '보통'-5점 '매우 그렇다'). 총 321개의 회수된 응답 중 불성실 응답 49 개의 자료를 제외한 272 명의 설문 응답 값을 표본으로 활용하였다.

성별에 있어서 전원 (272명, 100\%) 남성이었으며, 연령은 20세 이상 23세 미만 205명(75.4\%), 23 세 이상 26세 미만 63명(23.1\%), 26세 이상 4명(1.5\%)으로 분석되었다. 계급은 이병 12 명(4.4\%), 일 병 123명(45.2\%), 상병 102명(37.5\%), 병장 35명(12.9\%)로 분석되었으며, 복무기간은 6개월 미만 45 명(16.5\%), 6개월 이상 1년 미만 90명(33.1\%), 1년 이상 2년 미만 137명(50.4\%)의 분포를 보였다. 직책 유형으로는 일반 전투원 237명(87.1\%), 행정병 27명(9.9\%), 특수근무(취사병 등) 8명(2.9\%)으 로 분석되었다. 최종학력으로는 고졸 이하 38 명 $(14 \%)$, 대학 재학 221 명 $(81.3 \%)$, 대졸 6 명 $(2.2 \%)$, 기 
타 7 명 $(2.6 \%)$ 으로 분석되었다.

\section{2 변수의 조작적 정의 및 측정}

\subsection{1 군의 사회적 책임}

'군의 사회적 책임’은 전투력창출 $\mathrm{MSR}$, 법적 - 윤리적 MSR, 자선적 MSR, 전략적 MSR을 합한 값의 평균으로 정의하였다.

첫째, 전투력창출 MSR은 소속부대가 효과적이며 효율적인 전투력을 창출할 책임으로 정의한다. 기업이 만들어내는 경제적 성과는 모든 사회적 책임의 토대이며, 기업의 경제적 가치 창출은 기업 이 수행하는 가장 본질적인 책임 영역이라고 할 수 있다(Carroll, 1979). 이런 기업의 본질적 책임이 경제적 성과인 것과 같이, 군의 존재 목적과 군의 가장 본질적인 책임을 '전투력 창출 및 유지'로 판단하였으며, 이를 '전투력창출 MSR'으로 설정하였다. 해당 변수는 Maignan과 Ferrell(2001)의 측 정도구를 수정하여 총 4개 문항을 사용한다. 소속부대의 효과·효율적인 전투력 창출 여부에 대한 군 장병의 인식을 측정하였다. 측정도구의 신뢰도(Cronbach $a$ 값)는 .883로 나타났다.

둘째, 법적·윤리적 MSR은 '군(軍)이 사회가 정한 법적 - 윤리적 테두리 내에서 모든 이해관계 자의 기준 및 가치에 부합하는 행동을 하는 정도'를 의미한다. 소속부대 간부들의 법 준수 여부, 군 내 다양성 장려 및 차별방지와 관련한 내부 정책 존재 여부, 소속부대 윤리 지침 준수 여부, 불법적 행위에 대한 보고 절차 마련 여부 등 총 9개 문항으로 Maignan과 Ferrell (2001)의 측정도구를 사 용하여 측정하였다. 본 연구에서 측정도구의 신뢰도는 .928로 나타났다.

셋째, 자선적 MSR은 '군(軍) 본연의 임무(전투준비)와는 직접 관련이 없는 대민지원 활동, 기부, 자원봉사 등의 사회적 책임활동을 자발적으로 수행하는 정도'를 의미한다. 본 연구는 소속부대의 MSR활동에 대한 군 장병의 인식을 조사하기 위해, 현재 실제 시행되고 있는 다양한 군의 사회적 책임 활동에 대한 내용을 조사하여 전문가 집단의 지도와 검토 하에 자체 제작하였다. 설문문항은 '나의 소속부대는 지역사회 취약 계층을 위한 자원봉사활동을 적극적으로 실시한다.', '나의 소속부 대는 지역사회 환경보전을 위한 활동에 적극적으로 참여한다.', '나의 소속부대는 국가 혹은 지역사 회 재해 - 재난 상황 발생시 적극적으로 지원한다.' 등 총 7 문항이며, 측정도구의 신뢰도는 .925로 나타났다.

넷째, CSR 연구에서 전략적 CSR은 'doing well by doing good', 기업 활동으로 사회적 목표와 경제적 목표를 동시에 달성'을 의미한다. 본 연구에서 전략적 책임은 ‘군(軍)이 사회적 책임활동을 통해 군 조직의 다양한 목표들을 달성하는 정도'를 의미하며, Zhao, Lee, \& Moon(2019)의 측정 도 구를 활용, 소속부대 MSR 활동을 통한 부대의 목표 달성, 이미지 제고, 경쟁력 획득 등에 대한 군 장병의 인식을 조사하였다. 본 연구에서 측정도구의 신뢰도는 .889로 나타났다. 


\section{2 .2 조직시민행동}

조직시민행동은 '공식적인 보상시스템에 의해서 명백히 또는 직접적으로 인식되지는 않지만, 총 체적으로 볼 때 조직의 효과적 기능을 촉진하는 개인의 재량적 행동'(Organ, 1988)이다. 본 연구에 서는 군 장병의 직접적이고 자발적인 이타적 행동에 초점을 맞추어 측정하기 위해 '과도한 업무의 전우, 전입 신병 등에 대한 자발적인 도움' 여부를 묻는 Podsakoff, et al.(1990)의 ‘이타주의'에 관한 설문 문항(4개)을 사용하였다. 측정도구의 신뢰도는 .888로 나타났다.

\section{2 .3 평판}

평판은 '여러 이해 관계자에게 제공할 수 있는 군(軍)의 능력을 나타내는 군(軍)의 과거 행동과 결과의 긍정적인 인식' 또는 그 능력에 대한 종합적인 평가이다(Fombrun, et al., 2000). 본 연구에 서는 Fombrun, et al.(2000)의 평판지수를 활용하였으며, 6개의 하위 요소(정서적 호소, 제품과 서 비스, 비전과 리더십 등) 중 군 맥락에 맞는 핵심 문항을 각각 한 문항씩 선별하여(6개) 설문문항을 구성하였다. 본 연구에서 측정도구의 신뢰도(Cronbach a값)는 .940로 나타났다.

\subsection{4 통제변수}

본 연구는 연구모형에 포함된 변수들 혹은 변수 간의 관계에 유의한 영향을 미칠 수 있는 변수들 을 통제하였다. 군 장병들은 계급에 따라, 혹은 복무한 기간에 따라 그들이 인식하는 군의 사회적 책임 활동이 다르다. 더 오래 근무한 용사는 이등병보다 더 많은 경험과 지식을 가지고 있을 가능 성이 높기 때문이다. 이에 계급을 이병, 일병, 상병, 병장으로 나누었으며 이를 더미변수화 하여 통 제하였다. 또한, 육군의 경우 부대의 지리적 위치나 그 부대 임무에 따라 그들이 경험하는 사회적 책임 활동에 차이가 있다. 이에 부대형태(경계작전부대, 일반부대, 기타부대)를 더미변수화 하여 통 제하였다. 마지막으로 각 부대 특성뿐만 아니라 부대원 개개인의 직책 특성에 따라 일반전투원, 행 정병, 특수근무 순으로 통제변수를 측정하였으며 더미변수 처리하였다. 예를 들어, 행정병(계원)의 경우 주로 전역할 때까지 부대 사무실에서 행정업무를 하고, PX병 또한 일반적으로 PX업무만을 주로 본다. 반면, 일반 전투원은 훈련 또는 대민지원 활동 등 다른 특수 근무 용사들에 비해 다양한 경험을 한다. 따라서 해당 변수를 통제변수 처리하였다.

\section{3 분석 방법 및 절차}

연구가설을 통계적으로 검증하기 위해 SPSS 21.0과 Amos 18.0을 활용하였다. SPSS 21.0을 통 해 기술통계 및 신뢰도분석, 상관관계분석, 회귀분석 등을 실시하였으며, Amos 18.0의 구조방정식 모델(Structure Equation Model : $\mathrm{SEM}$ )을 통해 연구 2 모델의 적합성 및 개별 MSR과 $\mathrm{OCB}$ 의 관 계에서 평판의 매개효과를 검증하였다. 
신뢰도와 타당도를 검증하고자 확인적 요인분석을 실시하였다. 확인적 요인분석 과정에서 요인 적재값이 낮은 문항 1 개(법윤리적 책임, 문항 9)를 제거하였으며, 이를 제외한 분석 결과는 표 2 와 같다. 각 요인의 기각률(C.R.)은 모두 $\mathrm{p}<0.001$ 수준에서 유의하였으며, 각 요인의 개념신뢰도, AVE 값 모두 기준치(개념신뢰도=.7, AVE=.5, Hair et al., 2006)를 만족하였다. 추가적으로 연구에 사용 된 측정도구들의 내적일관성을 확인하기 위해 SPSS 21.0 을 활용하여 신뢰도를 검증하였다. 그 결 과 모든 변수의 Cronbach's a는 .70 이상(Nunnally, 1978)으로 나타나 신뢰도가 확보되었다. 다음으 로 연구모형의 적합도를 확인한 결과 각 지수의 값은 $\mathrm{X}^{2}=955.894(\mathrm{p}<.001), \mathrm{TLI}=.927, \mathrm{CFI}=.934$, RMSEA=.060으로 나타났다.

<표 2> 신뢰도와 타당도 분석

\begin{tabular}{|c|c|c|c|c|c|c|c|c|}
\hline \multirow{2}{*}{$\begin{array}{l}\text { 잠재 } \\
\text { 변수 }\end{array}$} & \multirow{2}{*}{ 측정변수 } & \multicolumn{2}{|c|}{ Estimate } & \multirow{2}{*}{ S.E. } & \multirow{2}{*}{ C.R. } & \multirow{2}{*}{ AVE } & \multirow{2}{*}{$\begin{array}{l}\text { 개념 } \\
\text { 신뢰도 }\end{array}$} & \multirow{2}{*}{$\begin{array}{l}\text { 신뢰도 } \\
\text { (C's a) }\end{array}$} \\
\hline & & B & $\beta$ & & & & & \\
\hline \multirow{4}{*}{$\begin{array}{l}\text { 전투력 } \\
\text { 창출 } \\
\text { 책임 }\end{array}$} & 전투력창출4 & 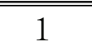 & ".738 & & & \multirow{4}{*}{.651} & \multirow{4}{*}{.882} & \multirow{4}{*}{.883} \\
\hline & 전투력창출3 & .981 & .813 & .074 & $13.295 * * *$ & & & \\
\hline & 전투력창출2 & 1.024 & .84 & .074 & $13.764 * * *$ & & & \\
\hline & 전투력창출1 & 1.052 & .881 & .073 & $14.426 * * *$ & & & \\
\hline \multirow{7}{*}{$\begin{array}{c}\text { 자선적 } \\
\text { 책임 }\end{array}$} & 자선적3 & 1 & .821 & & & \multirow{7}{*}{.629} & \multirow{7}{*}{.922} & \multirow{7}{*}{.925} \\
\hline & 자선적2 & .938 & .762 & .065 & $14.364 * * *$ & & & \\
\hline & 자선적1 & .818 & .774 & .056 & $14.664 * * *$ & & & \\
\hline & 자선적4 & .922 & .821 & .058 & $15.979 * * *$ & & & \\
\hline & 자선적5 & .843 & .801 & .055 & $15.41 * * *$ & & & \\
\hline & 자선적6 & .939 & .844 & .056 & $16.662 * * *$ & & & \\
\hline & 자선적7 & .864 & .782 & .058 & $14.876 * * *$ & & & \\
\hline \multirow{8}{*}{$\begin{array}{c}\text { 법윤리적 } \\
\text { 책임 }\end{array}$} & 법윤리적3 & 1 & .805 & & & \multirow{8}{*}{.608} & \multirow{8}{*}{.925} & \multirow{8}{*}{.928} \\
\hline & 법윤리적2 & .991 & .82 & .063 & $15.653 * * *$ & & & \\
\hline & 법윤리적1 & .928 & .813 & .06 & $15.463 * * *$ & & & \\
\hline & 법윤리적4 & 1.041 & .884 & .06 & $17.449 * * *$ & & & \\
\hline & 법윤리적5 & .994 & .791 & .067 & $14.891 * * *$ & & & \\
\hline & 법윤리적6 & .9 & .679 & .074 & $12.187 * * *$ & & & \\
\hline & 법윤리적7 & .786 & .709 & .061 & $12.886 * * *$ & & & \\
\hline & 법윤리적8 & .923 & .801 & .061 & $15.146 * * *$ & & & \\
\hline \multirow{4}{*}{$\begin{array}{l}\text { 전략적 } \\
\text { 책임 }\end{array}$} & 전략적1 & 1 & .685 & & & \multirow{4}{*}{.632} & \multirow{4}{*}{.872} & \multirow{4}{*}{.889} \\
\hline & 전략적2 & 1.29 & .819 & .105 & $12.313 * * *$ & & & \\
\hline & 전략적3 & 1.43 & .931 & .106 & $13.542 * * *$ & & & \\
\hline & 전략적4 & 1.277 & .849 & 0.1 & $12.707 * * *$ & & & \\
\hline \multirow{2}{*}{$\begin{array}{l}\text { 조직 } \\
\text { 시민 }\end{array}$} & OCB1 & 1 & .754 & & & \multirow{2}{*}{.769} & \multirow{2}{*}{.930} & \multirow{2}{*}{.888} \\
\hline & OCB2 & .948 & .776 & .073 & $12.939 * * *$ & & & \\
\hline
\end{tabular}




\begin{tabular}{|c|c|c|c|c|c|c|c|c|}
\hline \multirow{2}{*}{$\begin{array}{l}\text { 행동 } \\
\text { (이타) }\end{array}$} & OCB3 & 1.053 & .884 & .071 & $14.867 * * *$ & & & \\
\hline & OCB4 & 1.067 & .861 & .074 & $14.49 * * *$ & & & \\
\hline \multirow{6}{*}{ 평판 } & 평판1 & 1 & .824 & & & \multirow{6}{*}{.676} & \multirow{6}{*}{.926} & \multirow{6}{*}{.940} \\
\hline & 평판2 & .938 & .849 & .055 & $17.163 * * *$ & & & \\
\hline & 평판3 & 1.035 & .908 & .054 & $19.154 * * *$ & & & \\
\hline & 평판4 & 1.009 & .833 & .061 & $16.671 * * *$ & & & \\
\hline & 평판5 & .99 & .886 & .054 & $18.387 * * *$ & & & \\
\hline & 평판6 & .891 & .811 & .056 & $15.986 * * *$ & & & \\
\hline
\end{tabular}

\section{V. 연구결과}

\section{1 기초통계량 및 상관관계 분석}

가설 검증에 앞서 주요 변수인 군의 사회적 책임, $\mathrm{OCB}$, 평판과 군의 사회적 책임의 하위 차원인 전투력창출 $\mathrm{MSR}$, 법윤리적 $\mathrm{MSR}$, 자선적 $\mathrm{MSR}$ 에 대해 기술통계분석과 각 변수들 간의 상관관계 분석을 실시하였다. 주요결과(표 3), 첫째, 독립변수로서 개별 MSR 중 하나인 법윤리적MSR은 매 개변수인 평판과 높은 상관관계를 보였다( $\mathrm{r}=.727, \mathrm{p}<.001)$. 다소 높은 상관관계로 인해 다중공선성 문제가 제기될 수 있으나, 다중회귀분석을 통한 다중공선성 여부 확인한 결과, VIF가 10 을 초과하 지 않았다. 둘째, 군의 사회적 책임 및 하위차원인 개별 $\mathrm{MSR}$ (전투력창출, 법윤리적, 자선적, 전략 적) 간의 상관관계는 모두 통계적으로 유의하였으며 $(\mathrm{p}<.01)$, 상관관계가 높았다. 이는 본 연구에서 가정한 군의 사회적 책임과 그 하위차원 간의 관계를 지지하는 결과이다.

\section{2 가설검증}

\subsection{1 연구 1 가설 검증}

연구 1 은 군의 사회적 책임이 군 평판과 조직시민행동에 미치는 효과를 확인하고 평판의 매개효 과를 확인하기 위한 연구이다. SPSS의 위계적 회귀분석을 통해 가설을 검증하였다. 표 4의 모형 1 과 모형 3 은 통제변수와 종속변수만의 관계를 나타낸 것으로, 각각의 가설을 검증하기 위해, 그리 고 독립변수의 추가가 모형의 설명력 $\left(\mathrm{R}^{2}\right)$ 을 얼마나 향상시키는지 확인하기 위해 대조군으로 추가 하였다. 먼저, 가설 1 은 군의 사회적 책임활동이 군 평판에 대해 정적인 관계를 예측한다. 표 4의 모형 2 에서 볼 수 있듯이 이 두 변수는 유의미한 정 $(+)$ 적 관계를 나타냈으며 $(\mathrm{B}=.903, \mathrm{p}<.001)$, 따라 서 연구 1 의 가설 1 은 지지되었다. 가설 2 는 매개변수인 군 평판과 종속변수인 $\mathrm{OCB}$ 간의 정 $(+)$ 적인 관계이다. 표 5 의 모형 5 에서 두 변수 간의 유의미한 정적 관계를 확인하였으며 $(\mathrm{B}=.369, \mathrm{p}<.001)$, 
따라서 가설 2도 지지되었다. 이는 좋은 평판을 가진 부대에서 근무하는 군 장병은 그들의 조직시 민행동에 긍정적인 영향을 미친다는 것을 의미하며, 우호적인 평판을 갖는 조직에서 근무하는 것 자체가 조직에 대한 개인의 긍정적인 태도인 조직몰입에 긍정적인 영향을 미칠 수 있다는 Peterson(2004)의 연구와 맥을 같이 한다고 할 수 있다.

<표 3> 기초통계량과 상관관계

$(N=272)$

\begin{tabular}{|c|c|c|c|c|c|c|c|c|c|c|c|c|}
\hline 구 분 & 평균 & S.D. & 1 & 2 & 3 & 4 & 5 & 6 & 7 & 8 & 9 & 10 \\
\hline 1. 군의 사회적 책임 & 3.50 & .69 & & & & & & & & & & \\
\hline 2. 전투력창출MSR & 3.74 & .89 & $.753 * 2 k$ & & & & & & & & & \\
\hline 3. 법윤리적MSR & 3.77 & .84 & 860 kick & $.74 \% * 6 \%$ & & & & & & & & \\
\hline 4. 자선적MSR & 3.55 & .85 & $850 \%$ kck & $4 \sqrt{4} * 6 \%$ & $.667 * * 1 *$ & & & & & & & \\
\hline 5. 전략적MSR & 2.94 & .98 & $.665^{*} * 1 \%$ & $.167 * *$ & $316 * 2 k$ & $529 \%$ & & & & & & \\
\hline 6. 평판 & 3.36 & .99 & $.690 ; k 10 \%$ & $.614 \% \%$ & $.727 * * \alpha * k$ & $.607 * * \cdots * 2$ & $241 * \cdots 16$ & & & & & \\
\hline 7. 조직시민행동(이타) & 4.01 & .67 & $521 * \cdots$ & $.466 * 1 \%$ & $534 \% * 2$ & 418 wok & $.201 * *$ & 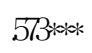 & & & & \\
\hline 8. 나이 & 22.09 & 1.21 & $-163 \%$ & -.051 & -.099 & $-172 * *$ & -180 k* & -.053 & -.031 & & & \\
\hline 9. 계급 & 2.59 & .77 & -.091 & .050 & -.099 & $-.139 *$ & -.098 & -.006 & -.012 & $297 * 010 k$ & & \\
\hline 10. 복무기간 & 2.34 & .75 & -.087 & .038 & -.065 & -.117 & $-.123 *$ & -.036 & .069 & $.208 * *$ & $.773^{*} \ldots k$ & \\
\hline 11. 최종학력 & 1.95 & .58 & -.061 & .019 & -.013 & -.077 & -.112 & -.010 & .018 & $.159 * *$ & .043 & .023 \\
\hline
\end{tabular}

모형 4는 군의 사회적 책임이 조직시민행동에 미치는 효과를 분석하는 모형이며, 모형 6 은 매개 변수인 군 평판이 추가되었을 때의 모형이다. 모형 4의 결과를 보면, 군의 사회적 책임이 조직시민 행동에 0.474(p<0.001)의 유의미한 효과를 보임으로써 가설 3이 지지 되었다. 모형 4와 모형 6을 비 교해보면 매개변수인 군 평판이 조직시민행동에 $0.251(\mathrm{p}<0.001)$ 의 유의미한 영향을 미치는 것으로 나타났다. 독립변수인 군의 사회적 책임이 미치는 영향력은 $0.474(\mathrm{p}<0.001)$ 에서 $0.247(\mathrm{p}<0.001)$ 로 줄어들었다. 이는 모두 통계적으로 유의한 가운데 그 영향력이 감소하였으므로 군 평판의 부분 매 개효과를 증명할 수 있으며, 따라서 가설 4도 지지가 되었다. 이러한 결과는 CSR이 조직구성원에 긍정적인 영향을 미친다는 선행연구의 결과를 지지하는 것으로 나타났다(Kwon \& Kang, 2012; Lin, et al. 2010; Rego, et al., 2010). 중간 메커니즘으로 평판은 군의 사회적 책임이 군 평판을 통해 부분적으로 군 장병의 조직시민행동의 일부를 설명할 수 있다.

\subsection{2 연구 2 가설 검증}

연구 2는 개별 MSR이 평판과 조직시민행동에 미치는 효과를 확인하고, 개별 MSR에 대한 평판 의 매개효과를 검증하였다. 가설 검증을 위한 모형평가 이전에 확인적 요인분석을 실행하였으며, 
The effect of military social responsibility perception on soldier's.. / Cheonseok Park • Jeman Jeon 149

적합도 지수 TLI, CFI, RMSEA를 종합적으로 요인구조를 결정하였다. 구조모형 적합도 지수는 만 족할 만한 수준으로 분석되었다 $\left(\mathrm{X}^{2}=955.894, \mathrm{TLI}=.927, \mathrm{CFI}=.934, \mathrm{RMSEA}=.060\right)$. 구조모형 분석 결 과는 개별 $\mathrm{MSR}$ 중, 자선적MSR과 법윤리적MSR은 평판에 정(+)적으로 유의한 영향을 미치는 것 으로 나타났다(자선적( $\beta=.271)$, 법윤리적( $\beta=.5), \mathrm{p}<.001)$. 또한 평판은 $\mathrm{OCB}$ 에 정 $(+)$ 적으로 유의한 영향을 미쳤다 $(\beta=.402, p<.001)($ 표 5$)$.

<표 4> 연구 1 회귀분석 결과 (군 평판 매개효과 검증)

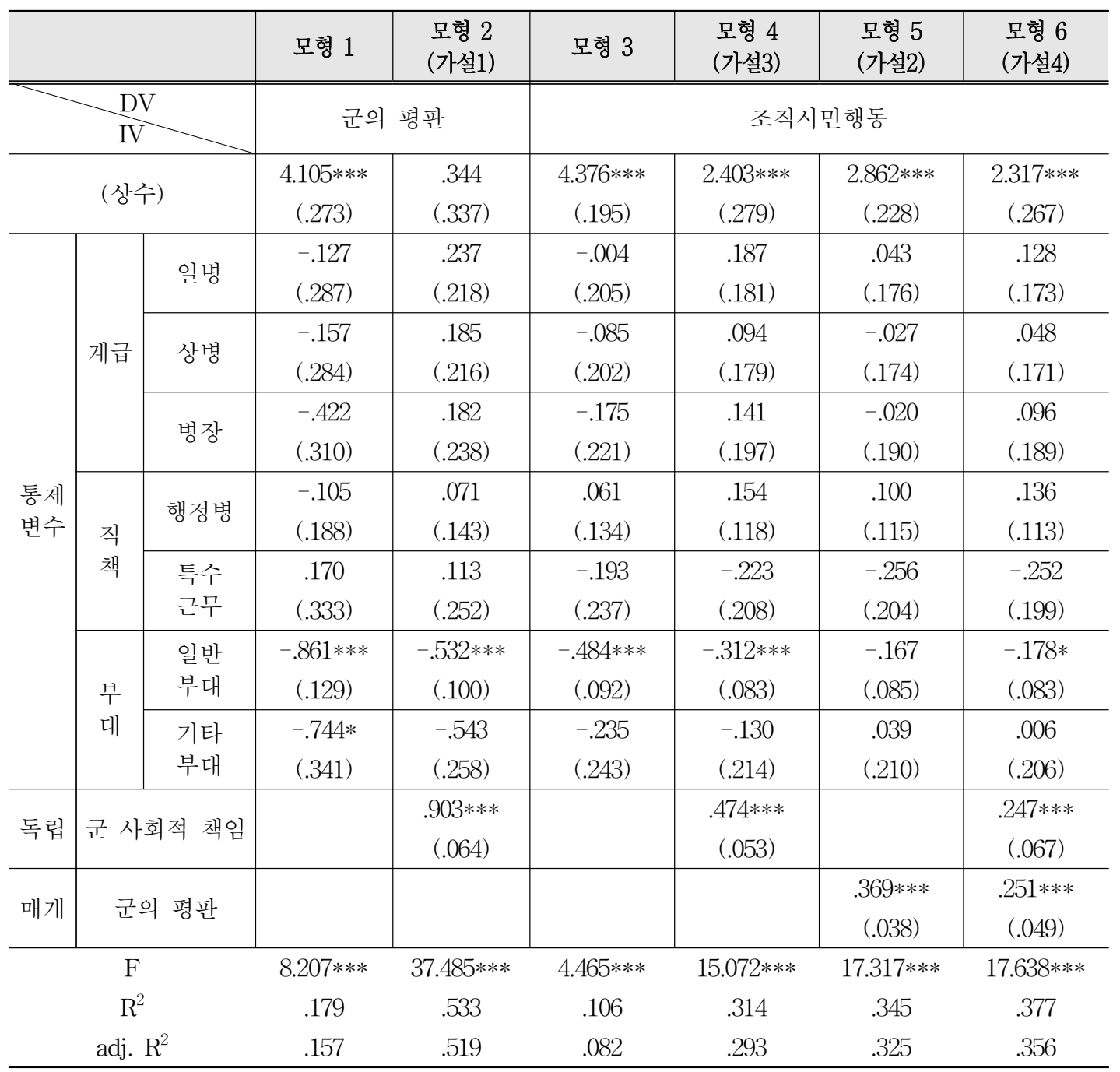

$* \mathrm{p}<0.05 * * \mathrm{p}<0.01 * * * \mathrm{p}<0.001$ 
<표 5> 연구 2 구조모형의 분석결과

$(\mathrm{N}=272)$

\begin{tabular}{|c|c|c|c|c|c|}
\hline \multirow{2}{*}{ 경 로 } & \multicolumn{2}{|c|}{ Estimate } & \multirow{2}{*}{ S.E. } & \multirow{2}{*}{ C.R. } & \multirow{2}{*}{$\mathrm{p}$} \\
\hline & B & $\beta$ & & & \\
\hline 전투력창출 $\rightarrow$ 평판 & 0.156 & 0.132 & 0.096 & 1.621 & .105 \\
\hline 자선적 $\rightarrow$ 평판 & 0.293 & $0.271^{* * * *}$ & 0.082 & 3.548 & .000 \\
\hline 법윤리적 $\rightarrow$ 평판 & 0.573 & $0.5^{* * *}$ & 0.12 & 4.778 & .000 \\
\hline 전략적 $\rightarrow$ 평판 & -0.119 & -0.09 & 0.07 & -1.718 & .086 \\
\hline 평판 $\rightarrow \mathrm{OCB}$ & 0.257 & $0.402^{* * *}$ & 0.062 & 4.161 & .000 \\
\hline 전투력창출 $\rightarrow \mathrm{OCB}$ & 0.102 & 0.135 & 0.077 & 1.331 & .183 \\
\hline 자선적 $\rightarrow \mathrm{OCB}$ & 0.08 & 0.116 & 0.067 & 1.193 & .233 \\
\hline 법윤리적 $\rightarrow$ OCB & 0.056 & 0.076 & 0.099 & 0.564 & .573 \\
\hline 전략적 $\rightarrow \mathrm{OCB}$ & -0.02 & -0.023 & 0.056 & -0.356 & .722 \\
\hline \multirow{2}{*}{ Model fit } & $x^{2}$ & $\mathrm{df}$ & TLI & CFI & RMSEA \\
\hline & 955.894 & 480 & .927 & .934 & .060 \\
\hline
\end{tabular}

$* \mathrm{p}<.05, * * \mathrm{p}<.01, * * * \mathrm{p}<.001$

개별 $\mathrm{MSR}$ 과 종속변수인 $\mathrm{OCB}$ 간의 관계에서 군 평판의 매개효과 검증을 위해 $\mathrm{AMOS}$ 를 이용하 여 부트스트래핑(Bias Corrected Bootstrapping) 검증을 500번의 부트스트랩으로 실시하여 95\%의 신뢰구간 값을 분석하였다. 분석결과, 자선적MSR-OCB 관계, 법윤리적MSR-OCB 관계에 군 평판 은 95\% 신뢰구간에서 0 을 포함하지 않는 것으로 나타나 군 평판의 매개효과는 $\mathrm{p}<.05$ 수준에서 통 계적으로 유의한 것으로 검증되었다. 따라서 표 5 와 표 6 의 결과를 종합하면, 군 평판은 자선적 $\mathrm{MSR}-\mathrm{OCB}$ 와 법윤리적MSR-OCB 관계에서 완전매개효과를 가지는 것으로 확인되었다. 이에 $\mathrm{H} 4 \mathrm{~b}$, $\mathrm{H} 4 \mathrm{c}$ 가 지지되었으며, $\mathrm{H} 4 \mathrm{a}, \mathrm{H} 4 \mathrm{~d}$ 는 기각되었다.

<표 6> 평판의 매개효과 부트스트래핑 검증 결과

\begin{tabular}{cccc}
\hline 경 로 & Estimate & S.E. & $95 \%$ 신뢰구간 \\
\hline \hline 전투력창출 $\rightarrow$ 평판 $\rightarrow \mathrm{OCB}$ & .040 & .029 & $-.019 \sim .106$ \\
자선적 $\rightarrow$ 평판 $\rightarrow \mathrm{OCB}$ & .075 & .037 & $.022 \sim .179$ \\
법윤리적 $\rightarrow$ 평판 $\rightarrow \mathrm{OCB}$ & .147 & .056 & $.061 \sim .308$ \\
전략적 $\rightarrow$ 평판 $\rightarrow \mathrm{OCB}$ & -.031 & .024 & $-.089 \sim .005$ \\
\hline
\end{tabular}




\section{VI. 논의 및 결론}

\section{1 연구결과 요약 및 시사점}

본 연구는 경영학 분야에서 이슈가 되고 있는 CSR 관련 연구를 군 맥락으로 확장하여, (1) 군의 사회적 책임이 군 평판과 조직시민행동에 미치는 효과, (2) 군의 사회적 책임과 조직시민행동 간의 관계에서 군 평판의 매개효과를 확인하였다. 주요 분석결과는 다음과 같다.

군의 사회적 책임은 군 평판과 조직시민행동에 모두 긍정적인 영향을 주는 것으로 나타났으며, 군 평판은 군의 사회적 책임과 조직시민행동 간의 관계를 부분매개하였다. 반면, 개별 MSR의 경 우, 법적 - 윤리적MSR과 자선적MSR은 평판에 의해 완전 매개 되었으며, 전투력창출MSR과 전략 적MSR은 매개효과를 보이지 않았다. Pyo(2012)의 연구에 따르면, 법 - 윤리적MSR과 자선적MSR 은 실천적 책임 요소, 전투력창출MSR과 전략적 MSR은 본질적 책임 요소로 구분할 수 있다. 연구 결과 평판은 본질적 책임 부분의 개별 $\mathrm{MSR}$ (전투력창출, 전략적)과 매개효과를 보이지 않았는데, 이는 장병들이 느끼기에 본질적 책임을 군인으로서 마땅히 해야 할 일들로 인식하기 때문에 이러 한 결과를 발생시켰을 것으로 해석할 수 있다. 혹은 군 장병들이 실제 군에 입대해 보니 군대가 그 들의 기대만큼의 충분한 전투력 창출 책임을 다하지 못하고 있어 별다른 자부심을 불러일으키지 않았을 수도 있다. 이는 차후 추가적인 연구가 필요하다.

본 연구는 다음과 같은 이론적 시사점을 갖는다. 첫째, 기존 CSR 연구틀(frame)을 통해 '군의 사 회적 책임'이라는 개념을 정립했다는데 의의가 있다. 군 조직은 ‘군의 사회적 책임’이라는 개념만 사용하지 않았을 뿐, 다양한 분야에서 다양한 형태로 사회적 책임을 묵묵히 다하고 있으며, 그러한 사회적 책임을 다하기 위한 법적, 제도적 노력들을 기울이고 있다. 그러나 군의 사회적 책임에 대한 관심 및 학문적인 개념 정립의 노력은 미비하였다. 따라서 본 연구는 기존에 학문적으로 잘 정립 되어진 '기업의 사회적 책임' 연구틀(frame)을 바탕으로 '군의 사회적 책임'에 대한 개념을 학문적 으로 정립하였다는데 의의를 갖는다.

둘째, 본 연구는 기업체와 종업원이 아닌 군 조직과 군 장병 대상으로 조사함으써 미시적 관점의 CSR 연구를 군(軍) 맥락으로 확장하였다는데 의의가 있다. 기존 CSR 연구들은 영리 행위를 추구 하는 기업체를 중심으로, 내부 이해관계자들이 인식하는 CSR이 그들의 태도나 행동에 미치는 영 향에 대해 조사하였다. 그러나 본 연구는 군에서 실시하는 군의 사회적 책임 활동이 군 장병의 이 타적 행동에 미치는 영향과 내부 메커니즘을 탐구한 학문적 의의가 있다.

셋째, 군의 사회적 책임 활동이 군 장병의 이타적 행동의 선행요인이라는 사실과 중간 메커니즘 으로서 군 평판이 이를 부분 매개함을 실증적으로 확인하였다. 이는 기업의 CSR 활동이 내부구성 원의 긍정적인 태도에 영향을 미칠 수 있다는 기존 연구결과(Brammer, et al., 2007; Cha, 2013; Park \& Hahn, 2011; Rupp, et al., 2013)와 평판이 이러한 조직구성원들의 CSR 인식과 긍정적 태도 
사이에서 중간 메커니즘으로서 매개 역할을 할 수 있다는 선행 연구들(Cho, et al., 2014; Kang \& $\mathrm{Han}, 2017)$ 과 같은 맥락이라 할 수 있다. 그래서 기업체의 조직구성원 뿐만 아니라 군조직의 장병 들도 그들의 조직시민행동(이타적 행동)이 그들이 인지하는 군의 사회적 책임 활동으로부터 긍정 적인 영향을 받는다는 것과 군 평판이 이를 부분적으로 매개함을 확인하였다.

그리고 본 연구는 군 조직의 사회적 책임 활동 운용 측면에서 다음과 같은 실무적 시사점을 제공 한다. 연구 2 에서 분석된 개별 MSR이 군 평판과 조직시민행동에 미치는 영향에 대한 결과를 확인 해보면, '법적 - 윤리적MSR'과 '자선적MSR'은 조직시민행동과 군 평판에 영향을 유의한 영향을 미 쳤으며, 군 평판은 법적 - 윤리적MSR과 자선적MSR을 완전 매개하였다. 반면, 전투력창출MSR과 전략적MSR은 아무런 영향을 미치지 않았다. 이는 '소속부대 간부들의 법 및 윤리지침 준수 여부, 군내 다양성 장려 및 차별 방지와 관련한 내부 정책 존재 여부, 불법적 행위에 대한 보고 절차 존재 여부' 등을 묻는 '법적 - 윤리적MSR'과 '군에서 현재 시행 중인 전투준비 외 자선적 활동 참여 여부' 를 묻는 '자선적MSR'이 군 장병의 조직에 대한 애착 혹은 자부심을 느끼게 하고, 조직에 대한 긍정 적인 사회정체성 형성에 영향을 주어 군 평판과 조직시민행동에 긍정적인 영향을 준다는 의미이다. $\operatorname{Song}(2018)$ 의 연구 결과에 따르면, 군 복무를 실시한 인원들이 군복무를 경험하지 않은 인원들보 다 일반적인 대군 신뢰도가 더 높았으며, 군 복무를 대군 신뢰도 향상의 기회로 활용할 가치가 있 음을 주장했다. 군 복무를 실시하는 모든 군 장병들은 복무기간 후 다시금 우리 국민으로 돌아가 간다. 따라서 군 조직에서 국민들의 대군 신뢰도 혹은 군의 평판을 향상시키기 위해서는 본 연구 결과를 고려하여 군의 사회적 책임 활동을 더욱 적극적으로 실시해야 하며, 이때 법적 - 윤리적 $\mathrm{MSR}$ 과 자선적MSR에 더 집중해야 한다. 얼핏 보면, '소속 부대 간부들의 법 및 윤리지침 준수 여 부, 불법적 행위에 대한 보고 절차 구비, 군내 다양성 장려 및 차별방지 정책 유무 등의 법적 - 윤리 적 MSR과 '대민지원, 봉사활동 등 지역사회 자선적 활동 참여'등의 자선적 MSR은 매우 당연해 보 이는 활동이지만, 이러한 MSR활동들에 대한 인식이 실제로 군 장병들의 군 평판을 향상시켜주며, 긍정적인 사회정체성 형성, 조직시민행동의 발현에 영향을 준다. 따라서 군은 정책적으로 군의 사 회적 책임 활동을 구체화 및 적극 활용하여 군복무기간을 군 장병들의 대군 신뢰도 및 군 평판 증 진의 장으로 활용해야 한다.

\section{2 연구 한계 및 향후 연구방향}

위와 같은 연구의 의의 및 시사점과 더불어 본 연구가 지니는 한계점은 다음과 같다.

첫째, 본 연구는 횡단 연구로서 단일 시점에 조사한 자료를 통해 분석 결과를 도출하였다. 단일 시점 자료를 통해 도출한 인과관계 주장은 역인과 관계를 제기할 수 있다는 점에서 한계를 갖는다. 차후에는 이러한 한계를 극복하고 심도 깊은 연구를 위해 측정 시점을 달리하는 등의 종단적 분석 이 필요하다. 
둘째, 이 연구에 사용된 변수들, 군의 사회적 책임 활동, 군 평판, 조직시민행동, 조직동일시는 모 두 동일한 인원으로부터 동일한 측정방법(설문조사)으로 자료획득을 하였다. 따라서 동일방법편의 (common method bias)문제가 존재한다(Park, et al., 2007). 추후 연구에서는 측정방법을 다양하게 하거나 상사 혹은 동료들로부터 측정하여 해당 오류 가능성을 제거 후 변수 간의 관계를 분석해 볼 필요가 있다.

셋째, 본 연구 결과를 모든 군(軍) 혹은 육군 전체로 일반화하는데 한계가 있다. 육군의 경우만 하 더라도 보병부대, 포병부대, 공병부대, 수송부대, 정보통신부대 등 다양한 임무와 역할에 따라 수행 하는 군의 사회적 책임 활동이 다양하며, 같은 보병부대라 할지라도 해부대의 지리적 위치에 따라 또한 그 활동의 종류가 다르다. 본 연구는 강원도 지역 3 개 부대, 수도권 지역 2 개 보병부대를 대상 으로 설문을 실시했기 때문에 그 결과를 전 군(軍) 혹은 전 육군으로 일반화하는데 어려움이 있다.

마지막으로 향후 연구는 용사들이 아닌 군 간부를 대상으로 군의 사회적 책임이 미치는 영향에 대한 연구를 제안한다. 본 연구의 연구대상은 용사이다. 즉, 대부분 선택이 아닌 의무로 군복무를 실 시하기 때문에 자발적으로 군 복무를 하는 군 간부들과는 모든 면에서 인식이 다를 수 있다. 현재 군은 국방개혁을 통해 군 간부의 비율을 높이고 있는 추세이다. 이러한 변화에 대비하여, 군 간부들 이 인식하는 군의 사회적 책임 활동이 그들의 긍정적 직무태도나 평판인식에 미치는 영향에 대해 연구해 볼 필요가 있다. 왜냐하면 미래 변화하는 안보환경에서 군의 사회적 책임활동은 더욱 다양화 되고 확대될 것이기 때문이다. 우리 군에 새롭게 부과되거나 혹은 확대될 사회적 책임 활동에 대한 성공적인 임무수행 여부는 결국 군 간부들에게 달려있다. 이는 곧 국민들이 인식하는 우리 군에 대 한 평가, 즉 평판과 직결되는바 이에 대한 MSR 연구는 중요하다고 할 수 있다. 민과 군은 서로에게 꼭 필요한 존재이며 상호 신뢰와 존중이 필요하다. 향후 군의 사회적 책임활동에 대한 연구는 상호 존중과 배려가 가득한 바람직한 민군관계를 조성하는데 중요한 역할을 담당할 수 있을 것이다.

\section{Acknowledgements}

We would like to thank Editage (www.editage.co.kr) for English language editing.

\section{Declaration of Conflicting Interests}

The author(s) declared no potential conflicts of interest with respect to the research, authorship, and/or publication of this article. 


\section{Reference}

Aguinis, H., \& Glavas, A. (2012). What we know and don't know about corporate social responsibility: A review and research agenda. Journal of Management, 38(4), 932-968. https://doi.org/10.1177/0149206311436079

Akturan, A., \& Şevik, N. (2016). The effect of corporation reputation on organizational citizenship behaviour. International Journal of Commerce and Finance, 2(1), 113-123. http://ijcf. ticaret.edu.tr/index.php/ijcf/article/view/24

Ashforth, B. E., \& Mael, F. (1989). Social identity theory and the organization. Academy of Management Review, 14(1), 20-39. https://doi.org/10.2307/258189

Brammer, S. J., \& Pavelin, S. (2006). Corporate reputation and social performance: The importance of fit. Journal of Management Studies, 43(3), 435-455. https://doi.org/10. 1111/j.1467-6486.2006.00597.x

Brammer, S., Millington, A., \& Rayton, B. (2007). The contribution of corporate social responsibility to organizational commitment. The International Journal of Human Resource Management, 18(10), 1701-1719. https://doi.org/10.1080/09585190701570866

Carroll, A. B. (1991). The pyramid of corporate social responsibility: Toward the moral management of organizational stakeholders. Business Horizons, 34(4), 39-48. https://doi.org/10.1016/0007-6813(91)90005-G

Cha, J. (2013). The Influence of Corporate Social Responsibility Activities on Prosocial Behaviors of Medical Doctors and Nurses. Korean Journal of Business Administration 26(3), 529-548. UCI : G704-000789.2013.26.3.001

Chang, Y., \& Ahn, C. (2012). Corporate Social Responsibility and Corporate Performance /Competitiveness. Korean Journal of Business Administration, 25(9), 3553-3577. UCI : G704-000789.2012.25.9.008

Cho, M., Kim, C., \& Yu, N. (2014). Influence of Employees' Perceived Corporate Social Responsibility on Organizational Commitment: Mediating Effect of Organizational Prestige. Journal of CEO and Management Studies, 17(4), 169-189. UCI : G704-SER 000009850.2014.17.4.009

Chun, R. (2005). Corporate reputation: Meaning and measurement. International Journal of Management Reviews, 7(2), 91-109. https://doi.org/10.1111/j.1468-2370.2005.00109.x

Davis, K., \& Blomstrom, R. L. (1966). Business and its environment. McGraw-Hill.

De Roeck, K., \& Maon, F. (2018). Building the theoretical puzzle of employees' reactions to 
The effect of military social responsibility perception on soldier's... / Cheonseok Park • Jeman Jeon 155

corporate social responsibility: An integrative conceptual framework and research agenda. Journal of Business Ethics, 149(3), 609-625. https://doi.org/10.1007/s10551-016-3081-2

Donaldson, T., \& Preston, L. E. (1995). The stakeholder theory of the corporation: Concepts, evidence, and implications. Academy of Management Review, 20(1), 65-91. https://doi.org/10.5465/amr.1995.9503271992

Fombrun, C. J., Gardberg, N. A., \& Sever, J. M. (2000). The Reputation Quotient SM: A multi-stakeholder measure of corporate reputation. Journal of Brand Management, 7(4), 241-255. https://doi.org/10.1057/bm.2000.10

Frederick, W. C. (1960). The growing concern over business responsibility. California Management Review, 2(4), 54-61. https://doi.org/10.2307/41165405

Fu, H., Li, Y., \& Duan, Y. (2014). Does employee-perceived reputation contribute to citizenship behavior? International Journal of Contemporary Hospitality Management, 26(4), 593-609. https://doi.org/10.1108/ijchm-02-2013-0082

Glavas, A., \& Godwin, L. N. (2012). Is the Perception of "Goodness" Good Enough? Exploring the Relationship Between Perceived Corporate Social Responsibility and Employee Organizational Identification. Journal of Business Ethics, 114(1), 15-27. https://doi.org/ $10.1007 / \mathrm{s} 10551-012-1323-5$

Gond, J. P., El Akremi, A., Swaen, V., \& Babu, N. (2017). The psychological microfoundations of corporate social responsibility: A person centric systematic review. Journal of Organizational Behavior, 38(2), 225-246. https://doi.org/10.1002/job.2170

Greening, D. W., \& Turban, D. B. (2000). Corporate social performance as a competitive advantage in attracting a quality workforce. Business \& Society, 39(3), 254-280. https://doi.org/10.1177/000765030003900302

Hair, J., Black, W., Babin, B., Anderson, R., \& Tatham, R. (2006). Multivariate data analysis (6th ed.), Uppersaddle River, N.J.: Pearson Prentice Hall.

Hwnag, M. (2012). Influence of Volunteer Activity and Service Stress in Barrack Soldiers upon Military Life Adjustment. Master's dissertation. Busan: Tongmyoung University Graduate School of Social Welfare.

Jung, H, \& Shin, M. (2016). Review of Korean Corporate Social Responsibility Studies in Management. Korean Journal of Management, 24(1), 103-145. UCI : G704-000359.2016. 24.1.002

Kang, S., \& Han, S. (2017). Employee's Perception of Corporate Social Responsibility, Corporate Reputation and Organizational Commitment. The Korean Academic Association of Business Administration, 30(9), 1653-1671. https://doi.org/10.18032/kaaba.2017.30.9.1653 
Katz, D., \& Kahn, R. L. (1978). The social psychology of organizations (Vol. 2). New York, NY: Willey.

Kim, J. (2000). A Study on the Discrimental Factors of Organizational Citizenship Behavior. Journal of Industrial Economics and Business, 13(1), 337-356. UCI : I410-ECN-0101-2013-323-000262565

Kim, S., \& Lee, K. (2013). Corporate Social Responsibility(CSR) in Accounting: Review and Future Direction. Korean Journal of Business Administration, 26(9), 2397-2425. UCI : G704-000789.2013.26.9.003

Kwon, K., \& Kang, S. (2012). The effects of Corporate Social Responsibility activities on Organizational Citizenship Behavior, Intention of Turnover - Focused on examining mediator effects of Affective Organizational Commitment. Korean Journal of Business Administration, 25(7), 3085-3105. UCI : G704-000789.2012.25.7.002

Lewis, S. (2001). Measuring corporate reputation. Corporate Communications: An International Journal, 6(1), 31-35. https://doi.org/10.1108/13563280110381198

Lin, C.-P., Lyau, N.-M., Tsai, Y.-H., Chen, W.-Y., \& Chiu, C.-K. (2010). Modeling Corporate Citizenship and Its Relationship with Organizational Citizenship Behaviors. Journal of Business Ethics, 95(3), 357 - 372. https://doi.org/10.1007/s10551-010-0364-x

Mael, F., \& Ashforth, B. E. (1992). Alumni and their alma mater: A partial test of the reformulated model of organizational identification. Journal of Organizational Behavior, 13(2), 103 - 123. https://doi.org/10.1002/job.4030130202

Maignan, I., \& Ferrell, O. (2001). Antecedents and benefits of corporate citizenship: An investigation of French businesses. Journal of Business Research, 51(1), 37-51. https://doi.org/10.1016/s0148-2963(99)00042-9

Mehtap, O., \& Kokalan, O. (2013). The relationship between corporate reputation and organizational citizenship behavior: a comparative study on TV companies and banks. Quality \& Quantity, 47(6), 3609-3619. https://doi.org/10.1007/s11135-012-9743-y

Minor, D., \& Morgan, J. (2011). CSR as Reputation Insurance: Primum Non Nocere. California Management Review, 53(3), 40 - 59. https://doi.org/10.1525/cmr.2011.53.3.40

Morhart, F. M., Herzog, W., \& Tomczak, T. (2009). Brand-specific leadership: Turning employees into brand champions. Journal of Marketing, 73(5), 122-142. https://doi.org/10. 1509/jmkg.73.5.122

Nunnally, J. C. (1978). Psychometric theory (2nd ed.). McGraw-Hill. Hillsdale, NJ.

Organ, D. W. (1988). OCB: The good soldier syndrome. In: Lexington, MA: Lexington Books. Park, H., \& Hahn, J. (2011). A Study on the Effect of CSR on Employees' Organizational 
The effect of military social responsibility perception on soldier's... / Cheonseok Park • Jeman Jeon 157

Commitment and OCB. Journal of Organization and Management, 35(3), 115-140. UCI : G704-000984.2011.35.3.007

Park, W., Kim, M., Jung, S., \& Huh, K. (2007). Cause and Remedies of Common Method Bias. Korean Journal of Management, 15(1), 89-133. UCI : G704-000359.2007.15.1.005

Peterson, D. K. (2004). The relationship between perceptions of corporate citizenship and organizational commitment. Business \& Society, 43(3), 296-319. https://doi.org/10.1177/ 0007650304268065

Podsakoff, P. M., MacKenzie, S. B., Moorman, R. H., \& Fetter, R. (1990). Transformational leader behaviors and their effects on followers' trust in leader, satisfaction, and organizational citizenship behaviors. The Leadership Quarterly, 1(2), 107-142. https://doi.org/10.1016/ 1048-9843(90)90009-7

Porter, M. E., \& Kramer, M. R. (2006). Strategy and Society: The link between competitive advantage and corporate social responsibility. Harvard Business Review, 84(12), 78-92. https://hbr.org/2006/12/strategy-and-society-the-link-between-competitive-advantage-a nd-corporate- ${ }^{-}$social-responsibility

Pyo, H. (2013). A Study on the Military's Social Responsibility (MSR) Strategy. Korean Association for Public Administration 2013 a Collection of Academic Presentation Papers, 1974-1986. https://www.kapa21.or.kr/data/kapa_data.php?mode=\&nopage=\&year=\& pdiv=\%C1\%A4\%B1\%E2\%C7\%D0\%BC\%FA\%B4\%EB\%C8\%B8\&writer=\%C7\%A5\%C7\%F $6 \% \mathrm{BB} \% \mathrm{~F} 3 \&$ subject=

Rayner, J. (2004). Managing reputational risk: Curbing threats, leveraging opportunities (Vol. 6). John Wiley \& Sons.

Rego, A., Ribeiro, N., \& Cunha, M. P. (2010). Perceptions of organizational virtuousness and happiness as predictors of organizational citizenship behaviors. Journal of Business Ethics, 93(2), 215-235. https://doi.org/10.1007/s10551-009-0197-7

Roman, R. M., Hayibor, S., \& Agle, B. R. (1999). The relationship between social and financial performance: Repainting a portrait. Business \& Society, 38(1), 109-125. https://doi.org/ 10.1177/000765039903800105

Rupp, D. E., Shao, R., Thornton, M. A., \& Skarlicki, D. P. (2013). Applicants' and employees' reactions to corporate social responsibility: The moderating effects of first party justice perceptions and moral identity. Personnel Psychology, 66(4), 895-933. https://doi.org/10. 1111/peps. 12030

Song, J. (2018). Restoring the Confidence of Korean Forces from National People under Sound Civil-Military Relations. Military Forum, 94, 195-223. 
Tajfel, H., \& Turner, J. C. (1985). The social identity theory of group behavior. Psychology of Intergroup Relations. Chicago: Nelson-Hall.

Turner, J. C. (1984). Social identification and psychological group formation. The Social Dimension, 518 - 538. https://doi.org/10.1017/cbo9780511759154.008

Yoo, Yong., (2016). In case of Disaster in terms of Comprehensive Security Study on the Role Increase of the Military. Master's dissertation. Seoul: Kyoungki University Graduate School of Political Studies.

Zhao, L., Lee, J., \& Moon, S. (2019). Employee response to CSR in China: the moderating effect of collectivism. Personnel Review, 48(3), 839 - 863. https://doi.org/10.1108/pr-05-20170146 


\section{군의 사회적 첵임 활동이 군 장병의 조직시민행동에 미치는 영향에 관한 연구}

박천석* • 전제만**

미래 한반도 안보환경의 변화가 증대되면서 군의 사회적 임무나 역할이 요구되고 있다. 이에 본 연구는 군 의 사회적 책임(Military Social Responsibility)에 대한 개념을 기업의 사회적 책임활동(Corporate Social Responsibility)을 토대로 정립하고, 군의 사회적 책임 활동이 장병 행동에 미치는 영향 관계를 밝히는 데 목적 을 두고 있다.

우선 $\mathrm{CSR}$ 관련 선행연구 고찰을 통해 군의 사회적 책임을 하위차원으로 전투력창출 $\mathrm{MSR}$, 법윤리적 MSR, 자선적 MSR, 전략적 MSR으로 분류하였다. 그리고 군의 사회적 책임이 군 맥락에서 작용하는 역할을 탐색하 기 위해 군 장병의 조직시민행동에 미치는 직접효과와 군 평판의 매개효과를 검증하였다. 통계분석을 위해 총 5 개 육군 부대의 장병을 대상으로 설문조사를 실시하여 272명의 설문을 수집하였다.

분석결과, 군 장병이 인식하는 군의 사회적 책임 활동은 군 장병의 조직시민행동에 유의한 정 $(+)$ 의 영향을 미쳤으며, 군 평판은 유의한 수준에서 부분 매개효과를 보였다. 또한, 개별MSR의 경우, 법적 · 윤리적MSR과 자선적MSR이 조직시민행동에 유의한 정(+)의 영향을 미쳤으며, 군 평판은 이를 완전 매개하였다. 본 연구의 분석결과를 바탕으로 이론적 시사점과 실무적 시사점, 연구의 한계를 도출하였으며, 향후 연구방안을 논의하 였다.

주제어 : 군의 사회적 책임, 평판, 조직시민행동, 사회적 정체성 이론, 매개효과

* (제1저자) 육군3사관학교 행정학과, 강사, parkchunseok@naver.com

** (공동저자) 서울시립대 학군단, 훈육관, wjswpaks@naver.com 
